\section{KAJIAN TATA KELOLA PENYEDIAAN TAMAN KOTA RAMAH HAM DI KABUPATEN WONOSOBO}

\author{
Fikri Farkhana*, Mardwi Rahdriawan \\ Departemen Perencanaan Wilayah dan Kota, Fakultas Teknik, \\ Universitas Diponegoro
}

\author{
Jurnal Pengembangan Kota (2018) \\ Volume 6 No. 2 (96-107) \\ Tersedia online di: \\ http://ejournal2.undip.ac.id/index.php/jpk \\ DOI: $10.14710 / j p k \cdot 6.2 .96-107$
}

\begin{abstract}
Abstrak. Kabupaten Wonosobo menjadi Kota Ramah Hak Asasi Manusia pada tahun 2014. Hal tersebut mengacu pada Deklarasi Gwangju guna mewujudkan kovenan HAM internasional. Bentuk implementasinya adalah melalui pembangunan taman kota ramah HAM yaitu Taman Kartini dan Taman Fatmawati. Permasalahan yang terjadi pada kedua taman adalah belum optimalnya tata kelola taman kota pada beberapa aspek seperti minimnya sosialisasi taman ramah HAM kepada masyarakat dan minimnya perawatan fasilitas taman yang rusak. Tujuan penelitian yaitu untuk mengkaji tata kelola taman kota di Kabupaten Wonosobo. Metode yang digunakan adalah metode penelitian kuantitatif. Data diperoleh melalui kegiatan telaah dokumen, observasi, kuesioner, dan wawancara terstruktur. Analisis dilakukan dengan analisis deskriptif kuantitatif terhadap kondisi taman dan tata kelola taman, serta analisis skoring data terhadap penilaian kondisi taman. Hasil dari penelitian ini menunjukkan kondisi taman kota dinilai baik sebesar $62,7 \%$. Namun, terdapat perbedaan tata kelola antara Taman Kartini dan Taman Fatmawati pada tahap pemeliharaan. Prinsip utama yang harus diakomodir pada tata kelola adalah prinsip partisipatif, prinsip akuntabilitas, dan prinsip transparansi.
\end{abstract}

Kata Kunci: ramah hak asasi manusia; taman kota; tata kelola

[Title: The Good Governance of Human Rights Urban Park in Wonosobo Regency]. Wonosobo Regency became as Human Rights City in 2014. This refers to the Gwangju Declaration to realize the international human rights covenant. The implementation is developing a human rights urban park, Kartini Park and Fatmawati Park. The problems that occur in both parks are that the urban park management is not optimal in several aspects, such as the lack of socialization of human rights park to the community and the lack of maintenance of damaged park facilities. This research studies the good governance of urban parks in Wonosobo Regency. The method used was quantitative research method. The data was obtained with document review, observation, questionnaire, and structured interview. Quantitative descriptive analysis was conducted on parks condition and governance, while data scoring analysis was conducted on park condition assessment. The results of this study indicate the condition of the urban park, which is considered good by $62,7 \%$. However, at the maintenance stage, there are several differences between Kartini Park and Fatmawati Park. The main principles that must be accommodated in human rights urban park governance are participatory, accountability and transparency.

Keywords: good governance; human rights city; urban park

Cara mengutip: Farkhana, F., \& Rahdriawan, M. (2018). Kajian Tata Kelola Penyediaan Taman Kota Ramah HAM di Kabupaten Wonosobo. Jurnal Pengembangan Kota. Vol 6 (2): 96-107. DOI: 10.14710/jpk.6.2.96-107

\section{PENDAHULUAN}

Ruang terbuka adalah suatu tempat yang dibuat karena adanya kebutuhan untuk tempat pertemuan dan aktivitas bersama pada udara terbuka (Budihardjo \& Sutarjo, 2009). Secara umum ruang terbuka terbagi atas ruang terbuka hijau (RTH) dan ruang terbuka non-hijau (RTNH). Salah satu bentuk ruang terbuka hijau adalah taman kota. Berdasarkan Peraturan Menteri Pekerjaan Umum Nomor 05/PRT/M/2008, taman kota adalah lahan terbuka yang berfungsi sosial dan estetik sebagai sarana kegiatan rekreatif, edukasi atau kegiatan lain pada tingkat kota. Taman kota adalah ruang terbuka hijau publik di

ISSN 2337-7062 (Print), 2503-0361 (Online) (C) 2018

This is an open access article under the CC-BY-NC-ND license (http://creativecommons.org/licenses/by-nc-sa/4.0/). - lihat halaman depan (C) 2018

*Email: farkhanaalatas@gmail.com

Diterima 29 Agustus 2018, disetujui 26 Oktober 2018 
sebuah perkotaan yang digunakan sebagai tempat masyarakat bertemu, berkumpul dan berinteraksi (Omar, Ibrahim, \& Mohamad, 2015). Sebagai salah satu perwujudan ruang terbuka hijau di perkotaan, taman kota memiliki peran penting bagi ekologi wilayah sehingga dapat meningkatkan kualitas hidup masyarakatnya (Frazier \& Bagchi-Sen, 2015). Pembangunan taman kota harus memenuhi kriteria pembangunan taman. Menurut Purnomohadi (2006), pembangunan taman kota harus memerhatikan lokasi, tujuan dan sasaran pembangunan taman, fungsi taman, desain taman, dan keamanan serta kenyamanan taman.

Saat ini telah banyak kabupaten atau kota yang melakukan pembangunan taman dengan tematema tertentu sesuai dengan kebutuhan masyarakat. Salah satu di antaranya adalah taman ramah hak asasi manusia. Taman ramah hak asasi manusia dibentuk untuk mendukung suatu kabupaten atau kota menjadi kota ramah hak asasi manusia. Taman kota ramah hak asasi manusia dapat diimplementasikan melalui tema-tema khusus seperti taman ramah anak, taman lansia, dan taman khusus penyandang difabel (Sarhan, Farghaly, \& Elsayed, 2016).

Konsep kota hak asasi manusia bermula pada tahun 1997, kemudian diartikan sebagai kota yang inklusif, adil dan nondiskriminatif (Pradjasto, Gofar, Louisa, \& Mugiyanto, 2015). Konsep tersebut kemudian dikembangkan oleh Forum Kota Hak Asasi Manusia Dunia (World Human Rights Cities Forum) yang dilakukan setiap tahun di kota Gwangju, Republik Korea Selatan. Forum dilaksanakan guna membahas prinsip-prinsip terkait kota hak asasi manusia. Hingga pada tanggal 17 Mei 2011 terbentuklah Deklarasi Gwangju tentang Kota Hak Asasi Manusia (Pradjasto, dkk., 2015). Berdasarkan hasil Deklarasi Gwangju tersebut, kabupaten atau kota ramah HAM adalah kabupaten atau kota yang mengupayakan peraturan kebijakan dan kelembagaan guna menghormati, melindungi dan memenuhi hak asasi manusia (World Human Rights Cities Forum, 2011). Kota ramah HAM dituntut untuk mampu melaksanakan dan mengawasi realisasi hak asasi manusia di wilayahnya.

Melalui Deklarasi Gwangju, konsep kota hak asasi manusia mulai diadopsi oleh negara-negara di dunia. Begitupula dengan Indonesia, Kabupaten
Wonosobo merupakan kabupaten yang mendeklasrasikan diri sebagai Kota Ramah Hak Asasi Manusia pada tahun 2014 (Wisnu, 2015). Tujuannya adalah menjadikan Wonosobo menjadi kota layak huni bagi semua lapisan masyarakat dengan mendapatkan pelayanan kebutuhan sebagai warga negara. Penetapan Wonosobo menjadi kota ramah HAM sesuai dengan Peraturan Daerah Kabupaten Wonosobo Nomor 5 Tahun 2016 dengan mengadopsi 6 prinsip kota ramah HAM. Berdasarkan hasil wawancara dengan Bappeda Kabupaten Wonosobo, Kabupaten Wonosobo sebagai kota ramah HAM mengusung lima pilar utama yaitu ramah anak, ramah lansia, ramah ibu hamil, ramah difabel, dan keberlanjutan lingkungan.

Salah satu bentuk implementasi untuk mewujudkan Wonosobo ramah hak asasi manusia adalah melalui pembangunan taman kota dengan kelengkapan taman yang sesuai dengan kebutuhan masyarakat sebagai penggunanya. Hingga di tahun 2017, Kabupaten Wonosobo telah memiliki delapan taman kota. Dua dari delapan taman merupakan taman kota yang menjadi percontohan taman ramah hak asasi manusia di Kabupaten Wonosobo. Taman yang dimaksud adalah Taman Kartini dan Taman Fatmawati.

Taman Kartini berada di Jalan Pemuda, Kecamatan Wonosobo. Lokasi taman yang dibangun pada tahun 2014 ini tepat berada di selatan Alun-Alun Wonosobo. Taman dengan luas $2.300 \mathrm{~m}^{2}$ tersebut dibangun melalui pendanaan dari APBN setelah mengikuti Program Pengembangan Kota Hijau (P2KH) yang diadakan oleh Kementerian Pekerjaan Umum dan Perumahan Rakyat. Pada tahun 2015, taman ini diberi predikat sebagai taman ramah anak oleh Tim Penggerak PKK Kabupaten Wonosobo.

Taman percontohan ramah HAM berikutnya adalah Taman Fatmawati. Taman Fatmawati berada di Jalan Banyumas, Kecamatan Wonosobo. Taman ini dibangun pada akhir tahun 2015 sebagai bentuk apresiasi karena Kabupaten Wonosobo menjadi kabupaten terbaik dalam menjalankan Program Pengembangan Kota Hijau (P2KH) di tahun 2014. Taman dengan luas sebesar 1,22 hektar tersebut mendapatkan pendanaan dari APBN serta tanggung jawab pengelolaan taman diberikan kepada Provinsi Jawa Tengah dan 
Kabupaten Wonosobo. Taman Fatmawati yang memang dirancang sebagai taman ramah hak asasi manusia, mengimplementasikan konsep tersebut ke dalam fasilitas-fasilitas yang ada di taman. Taman ini memiliki jalur bagi masyarakat dengan kebutuhan khusus berupa yellow line dan jalur landai serta ruang laktasi bagi ibu menyusui.

Meskipun banyak manfaat yang didapatkan dari keberadaan Taman Kartini dan Taman Fatmawati, namun pada kenyataannya kedua taman tersebut memiliki permasalahan yang dapat mengganggu fungsinya sebagai taman kota ramah HAM. Permasalahan Taman Kartini dan Taman Fatmawati ada pada tata kelola taman. Banyaknya stakeholder yang terlibat, minimnya koordinasi antar stakeholder, serta lambatnya respon stakeholder terkait kondisi taman kota merupakan masalah tata kelola yang terjadi. Masyarakat juga menilai beberapa fasilitas yang ada di taman kota kondisinya masih kurang baik.

Tata kelola pemerintahan yang baik merupakan suatu bentuk atau sistem pengelolaan yang bertanggung jawab dilakukan melalui pelibatan seluruh stakeholder dengan menggunakan prinsip demokrasi (Healey, 2015). Tata kelola pemerintahan yang baik dapat terjadi apabila seluruh stakeholder mempunyai tanggung jawab sesuai dengan peran dan kapasitasnya pada tahapan pembangunan (Suryokusumo, 2008). Tahapan pembangunan yang dimaksud meliputi tahap perencanaan, implementasi dan pemeliharaan. Pada prosesnya, pelaksanaan tata kelola pemerintahan dilakukan melalui pemenuhan prinsip-prinsip. Terdapat 5 prinsip tata kelola yang dikemukakan oleh Suryokusumo (2008) dan 12 prinsip tata kelola berdasarkan UndangUndang Nomor 25 tahun 2009 tentang Pelayanan Publik.

Berdasarkan prinsip tata kelola dan prinsip kota ramah hak asasi manusia yang telah disebutkan sebelumnya, terdapat enam prinsip yang dapat diterapkan di Kabupaten Wonosobo. Keenam prinsip tersebut merupakan prinsip yang perlu diakomodir untuk dapat mewujudkan tata kelola taman kota ramah hak asasi manusia. Prinsip yang digunakan telah disesuaikan dengan prinsip tata kelola yang baik dan tujuan Kabupaten Wonosobo sebagai kota ramah hak asasi manusia yang tercantum dalam Peraturan Daerah Kabupaten
Wonosobo Nomor 5 Tahun 2016. Prinsip yang dimaksud adalah sebagai berikut.

a. Partisipatif

Pelibatan dan peran serta antar stakeholder menjadi kunci terciptanya tata kelola pemerintahan tersebut. Stakeholder yang dimaksud adalah semua unsur pembangunan baik itu pemerintah, swasta maupun masyarakat.

b. Responsif

Prinsip responsif digunakan untuk melihat kemampuan pemerintah dalam memberikan pelayanan kepada masyarakat. Pemerintah dituntut untuk mampu menanggapi harapan, keinginan dan aspirasi masyarakat. Prinsip tersebut juga digunakan untuk memberikan penilaian terhadap layanan yang diberikan pemerintah terhadap masyarakat.

c. Akuntabilitas

Prinsip akuntabilitas mengandung arti bahwa kejelasan terkait pelaksanaan pelayanan publik harus mampu dipertanggungjawabkan. Adanya tanggung jawab dari pemerintah kepada masyarakat akan menimbulkan kepercayaan terhadap pelayanan publik tersebut.

d. Transparansi

Prinsip transparansi merupakan prinsip dimana adanya keterbukaan pada pelayanan publik. Transparansi dalam tata kelola pemerintah dapat berbentuk keterbukaan informasi agenda acara, perencanaan pembangunan hingga anggaran. Melalui prinsip tersebut masyarakat dapat ikut serta mengontrol dan mengawasi jalannya pemerintahan.

e. Efektivitas dan Efisiensi

Prinsip efektivitas dan efisiensi menjadi salah satu prinsip guna menciptakan tata kelola pemerintahan yang baik. Efektif berarti penyediaan layanan publik harus tepat sasaran dan sesuai dengan tujuan yang telah ditetapkan. Efisien berarti dalam menyediakan layanan publik bagi masyarakat, pemerintah harus mampu memanfaatkan sumber daya yang ada secara maksimal.

f. Keadilan sosial dan solidaritas yang berkelanjutan

Prinsip keadilan sosial dan solidaritas yang berkelanjutan berarti mengutamakan kesetaraan, kebersamaan, dan tumbuhnya modal sosial.

Penelitian serupa telah dilakukan oleh Yung, Conejos, dan Chan (2016) dengan judul Social Needs of the Elderly and Active Aging in Public Open 
Space. Penelitian tersebut mengidentifikasi terkait kebutuhan sosial lansia di ruang terbuka publik dengan adanya pedoman perencanaan dan standar desain ruang terbuka. Penelitian terkait lainnya dilakukan oleh Turan, Pulatkan, Beyazlı, dan Özen (2016). Judul dari penelitian tersebut adalah User Evaluation of the Urban Park Design Implementation with Participatory Approach Process. Pada penelitian tersebut membahas tentang pengaruh partisipasi dari stakeholder khususnya masyarakat dalam proses perencanaan taman kota. Penelian sejenis lainnya yaitu oleh Arts (2017), dengan judul Inclusive Sustainable Development: A Human Rights Perspective. Tujuan dari penelitian tersebut adalah melihat faktor pendukung pembangunan yang inklusif melalui norma-norma hak asasi manusia.

Berdasarkan penelitian terdahulu, penelitian ini mencoba mengaitkan tata kelola pemerintahan yang baik dengan isu ramah hak asasi manusia yang belum dilakukan pada penelitian sebelumnya. Penelitian ini lebih menekankan tentang bentuk tata kelola taman kota ramah hak asasi manusia di Kabupaten Wonosobo. Prinsip yang digunakan telah disesuaikan dengan kondisi di Kabupaten Wonosobo. Tujuan dilakukannya penelitian ini adalah untuk mengkaji tata kelola taman kota di Kabupaten Wonosobo dalam rangka mewujudkan kota ramah HAM. Terdapat empat sasaran untuk mencapai tujuan tersebut, yaitu mengidentifikasi tata kelola taman kota, menganalisis peran stakeholder, memberikan penilaian tata kelola saat ini, dan menganalisis bentuk tata kelola taman kota ramah hak asasi manusia di Kabupaten Wonosobo.

\section{METODE PENELITIAN}

Metode penelitian yang digunakan dalam penelitian ini adalah metode kuantitatif. Metode kuantitatif merupakan metode penelitian yang menggunakan teori untuk mengkaji suatu populasi (Syam, 2014) . Teknik pengumpulan data dilakukan dengan cara pengamatan langsung (observasi), kuesioner kepada pengunjung taman, wawancara terstruktur kepada Pemerintah Kabupaten Wonosobo, serta telaah dokumen melalui peraturan dan penelitian lain yang relevan.

Populasi untuk wawancara terstruktur adalah Pemerintah Kabupaten Wonosobo. Sampel penelitian yang digunakan sebagai responden wawancara terstruktur adalah dinas yang bertanggung jawab terhadap pengelolaan taman berjumlah 3 responden. Teknik yang dipilih adalah purposive sampling dimana sampel sudah ditentukan oleh peneliti sebelumnya. Dinas tersebut adalah Badan Perencanaan dan Pembangunan Daerah, Dinas Pekerjaan Umum dan Penataan Ruang, serta Dinas Lingkungan Hidup dan Kehutanan Kabupaten Wonosobo.

Populasi untuk teknik pengumpulan data dengan cara survei atau kuesioner adalah pengunjung Taman Kartini dan Taman Fatmawati. Sampel dalam penelitian yang selanjutnya digunakan sebagai responden kuesioner adalah sebagian pengunjung Taman Kartini dan Taman Fatmawati. Teknik yang dipilih adalah accidental sampling di mana responden dipilih secara kebetulan yang dianggap cocok dengan karakteristik sampel. Jumlah sampel ditentukan melalui rumus Rao Purba (Cochran, 2001). Rumus tersebut digunakan karena jumlah populasi belum dapat ditentukan jumlahnya. Penentuan jumlah sampel dihitung menggunakan rumus:

$$
\mathrm{n}=\frac{Z^{2}}{4(M o e)^{2}}
$$

Keterangan:

$\mathrm{n}=$ Ukuran sampel

$\mathrm{Z}=$ Tingkat keyakinan yang dibutuhkan

Moe $=$ Margin of Error

Jumlah sampel pengunjung taman kota ditentukan dengan tingkat keyakinan $95 \%$ atau $Z=1,96$. Batas ketelitian (Moe) yang diinginkan adalah 10\%. Maka sampel yang diperoleh adalah:

$\mathrm{n}=\frac{Z^{2}}{4(M o e)^{2}}$

$\mathrm{n}=\frac{(1,96)^{2}}{4(0,1)^{2}}=\frac{3,84}{0,04}=96 \approx 100$ orang responden

Teknik analisis yang digunakan pada penelitian ini adalah analisis deskriptif kuantitatif dan analisis skoring data. Analisis deskriptif dilakukan dengan cara memberikan gambaran terhadap data yang ada. Penyajian data pada analisis ini dapat berupa tabel, grafik, diagram, dan perhitungan statistik (Nazir, 2003). Analisis skoring data merupakan analisis yang digunakan untuk memberikan penilaian terhadap pertanyaan penelitian (Nazir, 2003).

Guna mendapatkan hasil penelitian yang valid dan reliabel, maka perlu dilakukan uji validitas dan uji 
reliabilitas. Uji validitas dan uji reliabilitas bertujuan untuk mengetahui sejauh mana kuesioner yang dibuat tepat dan dapat diandalkan pada sebuah penelitian (Sugiyono, 2007). Jumlah kuesioner yang diuji adalah $20 \%$ dari total kuesioner yaitu 20 kuesioner. Uji validitas dan reliabilitas dilakukan pada bagian penilaian masyarakat. Terdapat 16 butir pertanyaan yang akan diuji. Pengujian dilakukan dengan bantuan aplikasi Statistical Package for the Social Science (SPSS) versi 17.0. Hasil dari dilakukannya uji validitas dan uji reliabilitas menunjukkan bahwa instrumen penelitian valid dan reliabel. Instrumen dikatakan valid karena nilai $r_{\text {hitung }}$ lebih besar daripada $r_{\text {tabel }}$ yang bernilai 0,444 .

Tabel 1. Hasil Uji Validitas

\begin{tabular}{cccc}
\hline No & rhitung & rtabel $_{1}$ & Keterangan \\
\hline C1 & 0,607 & 0,444 & Valid \\
C2 & 0,575 & 0,444 & Valid \\
C3 & 0,664 & 0,444 & Valid \\
C4.1 & 0,706 & 0,444 & Valid \\
C4.2 & 0,645 & 0,444 & Valid \\
C4.3 & 0,447 & 0,444 & Valid \\
C4.4 & 0,692 & 0,444 & Valid \\
C4.5 & 0,513 & 0,444 & Valid \\
C4.6 & 0,547 & 0,444 & Valid \\
C4.7 & 0,777 & 0,444 & Valid \\
C4.8 & 0,518 & 0,444 & Valid \\
C4.9 & 0,585 & 0,444 & Valid \\
C4.10 & 0,650 & 0,444 & Valid \\
C4.11 & 0,657 & 0,444 & Valid \\
C5 & 0,673 & 0,444 & Valid \\
C6 & 0,515 & 0,444 & Valid \\
\hline
\end{tabular}

Instrumen juga dikatakan reliabel karena nilai koefisien Alfa Cronbach lebih besar dari nilai $r_{\text {tabel }}$ yaitu sebesar 0,884 . Hal tersebut menunjukkan bahwa instrumen penelitian dapat digunakan untuk pengambilan data.

Tabel 2. Hasil Uji Reliabilitas

\begin{tabular}{cc}
\hline Alfa Cronbach & $\mathbf{N}$ \\
\hline 0,884 & 16 \\
\hline
\end{tabular}

\section{HASIL DAN PEMBAHASAN}

\subsection{Tata Kelola Taman Kota di Kabupaten Wonsoobo}

Taman Kartini dan Taman Fatmawati merupakan taman kota ramah hak asasi manusia di Kabupaten Wonosobo. Kondisi Taman Kartini dan Taman Fatmawati sudah cukup terawat. Taman Kartini diresmikan dan mulai dibuka untuk umum pada tahun 2014. Taman yang diberi predikat sebagai taman ramah anak oleh Tim Penggerak PKK Kabupaten Wonosobo ini terletak di pusat kota sekaligus menjadi salah satu landmark Kabupaten Wonosobo melalui sainase "Wonosobo Asri" yang terdapat pada bagian depan taman tersebut. Taman Kartini memiliki fasilitas seperti wahana permainan anak, kolam air mancur, amphi theater dan lain sebagainya.

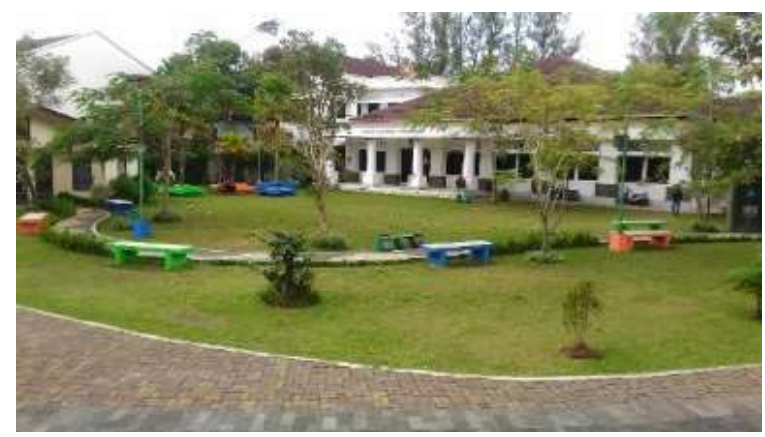

Gambar 1. Kondisi Taman Kartini

Berbeda dengan Taman Kartini, Taman Fatmawati terletak di bagian selatan Kabupaten Wonosobo. Tujuan adanya taman ini adalah untuk memecah konsentrasi kegiatan rekreasi yang ada di pusat kota. Taman Fatmawati mulai dibangun pada tahun 2015 dan dibuka untuk umum pada tahun 2016. Taman Fatmawati memang direncanakan sebagai taman ramah hak asasi manusia. Taman ini sempat mendapat kunjungan dari Komisi Perlindungan Anak Indonesia (KPAl) untuk menilai kesiapan Taman Fatmawati sebagai taman ramah hak asasi manusia di Kabupaten Wonosobo. Fasilitas yang ada di Taman Fatmawati antara lain ruang laktasi, lintasan lari, dan jalur bagi masyarakat dengan kebutuhan khusus.

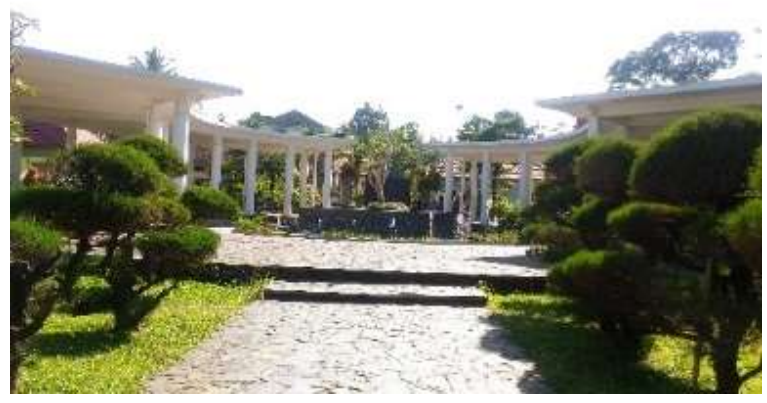

Gambar 2. Kondisi Taman Fatmawati

Namun, terdapat fasilitas-fasilitas yang perlu dilakukan peremajaan, peningkatan, serta penambahan. Fasilitas yang perlu ditingkatkan dan 
peremajaan adalah pengelolaan sampah, pengelolaan parkir, dan fasilitas ramah hak asasi manusia seperti jalur bagi masyarakat dengan kebutuhan khusus dan ruang laktasi. Fasilitas taman yang perlu diadakan penambahan adalah toilet, wahana bermain anak, dan vegetasi peneduh. Taman Kartini dan Taman Fatmawati dimanfaatkan masyarakat untuk melakukan berbagai kegiatan mulai dari aktivitas fisik, sosial, budaya dan ekonomi.

Taman Kartini dan Taman Fatmawati adalah taman kota ramah hak asasi manusia. Pada sistem tata kelolanya terdapat kerjasama antara pemerintah, swasta dan masyarakat (Healey, 2015). Perbedaan tata kelola antara kedua taman terdapat pada tahap pemeliharaan (lihat Gambar 3). Tanggung jawab pemeliharaan Taman Kartini berada di Dinas Kabupaten Wonosobo. Berbeda dengan Taman Fatmawati, tanggung jawab berada di Pemerintah Provinsi Jawa Tengah, dan Pemerintah Kabupaten Wonosobo.

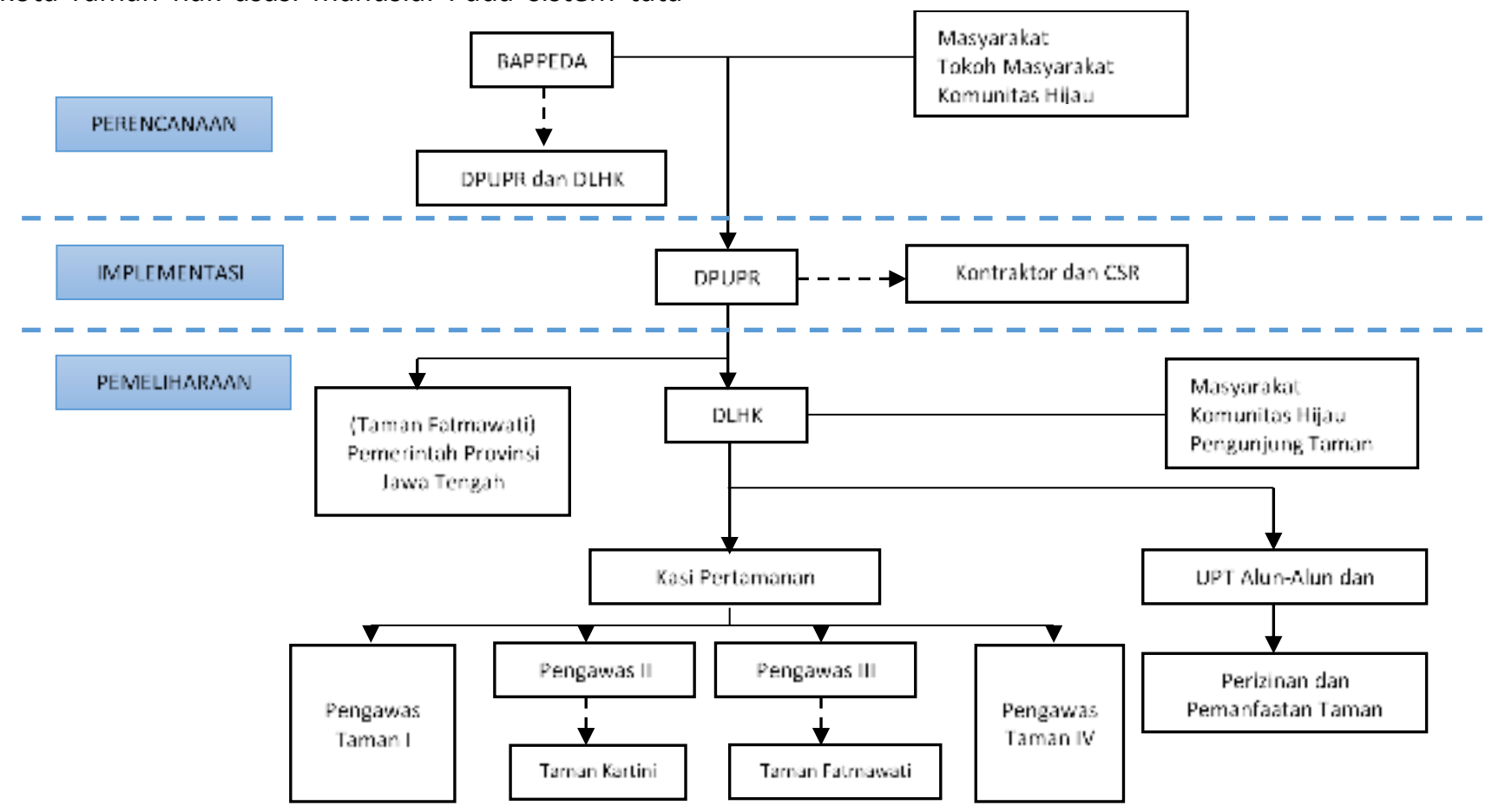

Gambar 3. Sistem Tata Kelola Taman Kota

\subsection{Peran Stakeholder}

Peran stakeholder dalam tata kelola taman kota di Kabupaten Wonosobo meliputi peran dari pemerintah yang bekerjasama dengan swasta dan peran dari masyarakat. Pemerintah maupun masyarakat memiliki peran masing-masing dalam tata kelola taman kota (lihat Tabel 3).

Tabel 3. Peran Stakeholder Pada Tata Kelola Taman Kota

\begin{tabular}{|c|c|c|c|c|c|}
\hline \multirow{2}{*}{ Tahap } & \multicolumn{4}{|c|}{ Pemerintah } & \multirow{2}{*}{ Masyarakat } \\
\hline & Dinas & & Tugas & & \\
\hline Perencanaan & BAPPEDA & $\begin{array}{l}\text { Menyusun } \\
\text { program } \\
\text { implementa }\end{array}$ & $\begin{array}{l}\text { proposal } \\
\text { P2KH } \\
\text { taman kota. }\end{array}$ & $\begin{array}{r}\text { kegiatan } \\
\text { melalui }\end{array}$ & $\begin{array}{l}\text { Memberikan usulan/masukan/ } \\
\text { gagasan terhadap rencana } \\
\text { pembangunan taman kota yang } \\
\text { diwakilkan oleh tokoh } \\
\text { masyarakat dan komunitas } \\
\text { hijau. }\end{array}$ \\
\hline
\end{tabular}




\begin{tabular}{|c|c|c|c|}
\hline \multirow{2}{*}{ Tahap } & \multicolumn{2}{|r|}{ Pemerintah } & \multirow{2}{*}{ Masyarakat } \\
\hline & Dinas & Tugas & \\
\hline Implementasi & Dinas PUPR & $\begin{array}{l}\text { - Membuat desain taman sesuai } \\
\text { dengan ketentuan } \mathrm{P} 2 \mathrm{KH} \text {. } \\
\text { - Bersama dengan kontraktor } \\
\text { bertanggung jawab dalam proses } \\
\text { pembangunan taman kota. } \\
\text { - Melakukan pemeliharaan selama } \\
6 \text { bulan pasca pembangunan. }\end{array}$ & - \\
\hline Pemeliharaan & $\begin{array}{l}\text { Taman Kartini } \\
\text { - Dinas LHK } \\
\text { Taman Fatmawati } \\
\text { - Dinas LHK } \\
\text { - Pemerintah } \\
\text { Provinsi Jawa } \\
\text { Tengah }\end{array}$ & $\begin{array}{l}\text { - Melakukan pengawasan jalannya } \\
\text { - Memeliharaan Taman Fatmawati. } \\
\text { pelakukan perawatan dan } \\
\text { - Mengawasi pemanfaatan taman. } \\
\text { - Melakukan pembibitan. } \\
\text { - Membina komunitas hijau. }\end{array}$ & $\begin{array}{l}\text { - Komunitas hijau dapat } \\
\text { melakukan kegiatan positif } \\
\text { untuk memanfaatkan taman } \\
\text { kota. } \\
\text { - Masyarakat umum wajib } \\
\text { untuk menjaga kebersihan } \\
\text { taman, tidak merusak } \\
\text { fasilitas yang ada dan } \\
\text { memanfaatkan taman untuk } \\
\text { hal-hal yang positif. }\end{array}$ \\
\hline
\end{tabular}

\subsection{Penilaian Taman Kota Ramah HAM}

Penilaian dilakukan pada setiap elemen taman (lihat Tabel 4). Apabila dalam penilaian terdapat elemen yang dinilai tidak baik, maka dapat dijadikan masukan guna perbaikan selanjutnya. Penilaian dilakukan dengan menggunakan analisis skoring. Data yang digunakan merupakan data kuesioner kepada pengunjung taman yang berjumlah 100 responden kemudian dilakukan skoring oleh peneliti. Analisis skoring bertujuan untuk melihat secara keselurahan apakah tiap elemen dalam tata kelola taman kota ramah hak asasi manusia sudah baik atau belum (Nazir, 2003).

Tabel 4. Hasil Skoring dan Intepretasi Kondisi Taman Kota

\begin{tabular}{lcc}
\hline \multicolumn{1}{c}{ Elemen yang Dinilai } & Nilai & Intepretasi \\
\hline Pemahaman responden terhadap taman kota ramah HAM & $\mathbf{5 4 , 2} \%$ & Cukup Paham \\
Kemudahan akses menuju taman & $80,2 \%$ & Mudah \\
Kondisi taman kota saat ini & $66,2 \%$ & Terawat \\
Kondisi air bersih & $69,2 \%$ & Baik \\
Kondisi sarana keamanan & $69,6 \%$ & Baik \\
Kondisi tanaman (rumput/bunga/pohon) & $74,4 \%$ & Baik \\
Kondisi bangku taman & $71,6 \%$ & Baik \\
Kondisi lampu taman & $69,4 \%$ & Baik \\
Kondisi sarana persampahan & $68,2 \%$ & Baik \\
Kondisi tempat olahraga & $64,0 \%$ & Baik \\
Kondisi tempat bermain anak & $\mathbf{5 5 , 6 \%}$ & Cukup \\
Kondisi tempat parkir & $66,8 \%$ & Baik \\
Kondisi toilet & $62,8 \%$ & Baik \\
Kondisi fasilitas ramah HAM (jalur khusus difabel, ruang laktasi) & $61,8 \%$ & Baik \\
Keamanan responden ketika ada di taman & $72,6 \%$ & Aman \\
Tingkat kepuasan responden ketika mengunjungi taman & $68,4 \%$ & Puas \\
\hline
\end{tabular}

Berdasarkan hasil tersebut dapat dikatakan bahwa penilaian kondisi taman kota pada Taman Kartini dan Taman Fatmawati sudah baik dengan nilai rata- rata $62,7 \%$. Hanya terdapat beberapa elemen yang perlu dibenahi seperti pemahaman masyarakat terkait taman kota ramah hak asasi manusia dan 
perbaikan tempat permainan anak. Terkait pemahaman masyarakat tentang taman kota ramah hak asasi manusia yang masih minim dapat disiasati melalui sosialisasi baik secara langsung ataupun melalui media. Terkait dengan tempat bermain anak yang dinilai masih kurang, Pemerintah Kabupaten Wonosobo dapat mulai merencanakan tempat bermain atau mengganti permainan anak yang sudah ada sebelumnya. Apabila diperlukan dapat bekerjasama dengan pihak swasta dalam bentuk CSR untuk pengadaan fasilitas tersebut.

\subsection{Bentuk Tata Kelola Taman Kota Ramah HAM di Kabupaten Wonosobo}

Menurut (Healey, 2015), tata kelola pemerintahan yang baik dapat tercapai dengan adanya partisipasi antar stakeholder dan mengakomodir prinsipprinsip tata kelola. Tata kelola taman kota ramah hak asasi manusia ditinjau melalui stakeholder yang terlibat, prinsip pembangunan taman kota pada tiap tahapan dan enam prinsip tata kelola taman kota ramah hak asasi manusia yang sudah dijelaskan sebelumnya. Pada penelitian ini tata kelola dinilai pada tiap tahapan pembangunan taman kota. Tahapan pembangunan taman meliputi tahap perencanaan, tahap implementasi dan tahap pemeliharaan.

Pada tahap perencanaan, dinas yang bertanggung jawab adalah Badan Perencanaan Daerah Kabupaten Wonosobo. Bukan hanya Bappeda, namun pelibatan masyarakat juga dibutuhkan pada tahap ini. Prinsip tata kelola ramah hak asasi yang digunakan pada tahap ini adalah prinsip partisipatif, prinsip akuntabilitas, dan prinsip transparansi. Selain prinsip tata kelola, prinsip pembangunan taman kota juga perlu diperhatikan.
Prinsip tersebut meliputi prinsip pemilihan lokasi, penetapan tujuan dan sasaran, penetapan fungsi taman.

Dinas Pekerjaan Umum dan Penataan Ruang Kabupaten Wonosobo bertanggung jawab dengan tata kelola pada tahap implementasi. Pada tahap ini, Dinas PUPR akan berkerja sama dengan pihak swasta yaitu kontraktor dalam proses pembangunan taman dan perusahaan-perusahaan swasta dalam proses pengadaan fasilitas taman melalui program CSR. Prinsip tata kelola ramah hak asasi manusia yang diakomodir pada tahap implementasi adalah prinsip partisipatif, prinsip akuntabilitas, prinsip transparansi, prinsip efektivitas, dan efisiensi serta prinsip keadilan sosial dan solidaritas yang berkelanjutan. Pembangunan taman juga harus memerhatikan prinsip terkait dengan desain taman.

Dinas yang bertanggung jawab pada tahap pemeliharaan adalah Dinas Lingkungan Hidup dan Kehutanan Kabupaten Wonosobo. Masyarakat juga ikut terlibat pada tahap pemeliharaan melalui komunitas hijau dan perilaku pengunjung taman untuk dapat memelihara dan merawat taman kota. Prinsip tata kelola ramah hak asasi manusia yang terdapat pada tahap ini adalah prinsip partisipatif, prinsip responsif, prinsip akuntabilitas, prinsip transparansi, serta prinsip efektivitas dan efisiensi. Pemeliharaan taman juga perlu memerhatikan prinsip keamanan dan kenyamanan pengguna taman. Adapun bagan tata kelola di Taman Kartini pada tahap perencanaan, implementasi dan pemeliharaan beserta penilaian pada tiap prinsipnya dapat dilihat pada Gambar 4 dan Taman Fatmawati pada Gambar 5. 


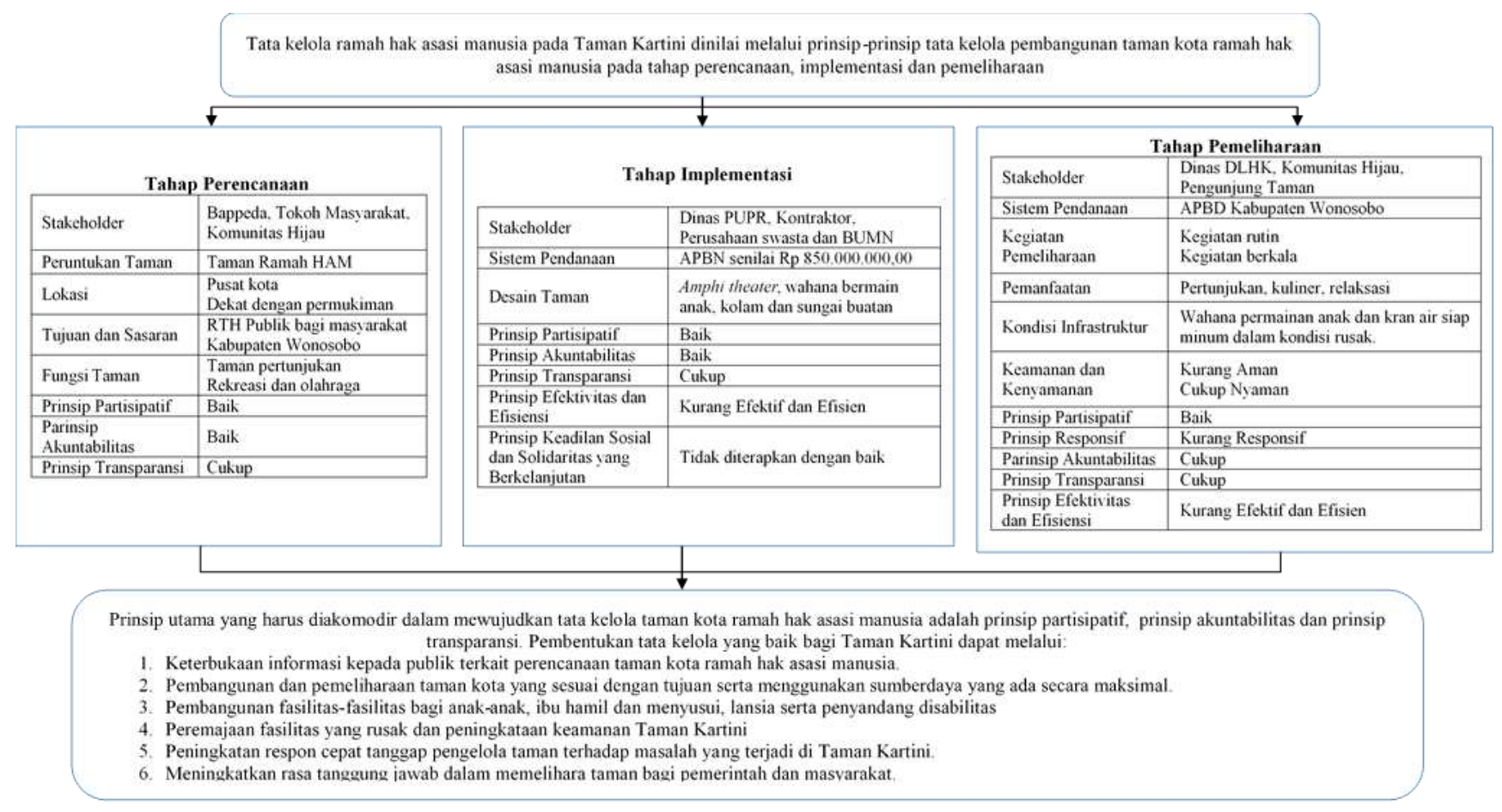

\section{Gambar 4. Bagan Tata Kelola Taman Kartini}

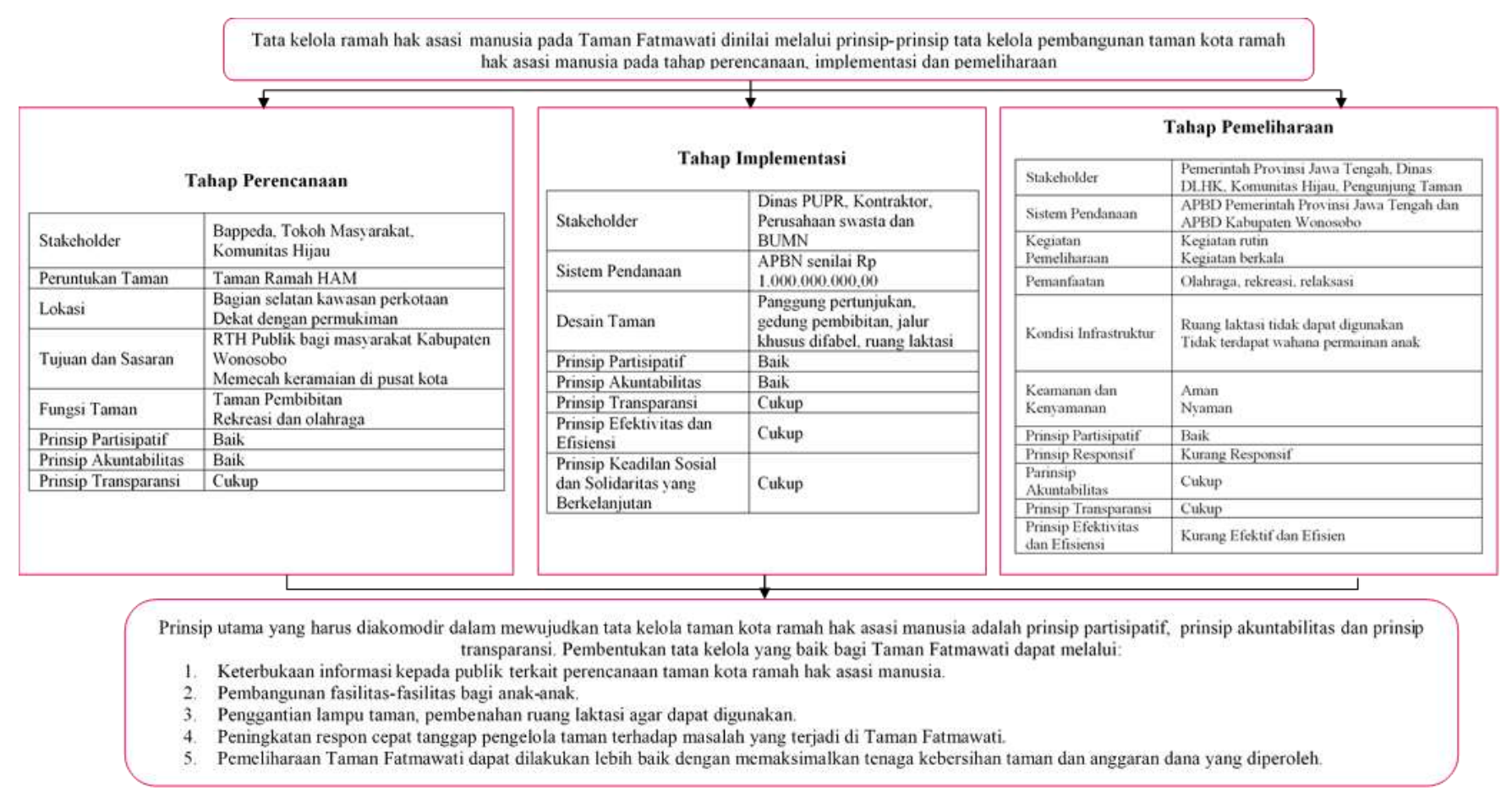

Gambar 5. Bagan Tata Kelola Taman Fatmawati

\section{KESIMPULAN}

Taman kota ramah hak asasi manusia merupakan ruang terbuka hijau publik sebagai bentuk implementasi kota ramah hak asasi manusia. Melalui hal tersebut, tujuan Pemerintah Kabupaten Wonosobo untuk menyediakan ruang terbuka hijau publik yang dapat diakses oleh semua kalangan masyarakat sudah tercapai dengan adanya Taman Kartini dan Taman Fatmawati.

Tata kelola taman kota ramah hak asasi manusia di Kabupaten Wonosobo dapat dikaji dengan melihat stakeholder yang terlibat, penerapan prinsip pembangunan taman kota dan penerapan 
prinsip tata kelola ramah hak asasi manusia. Hasil akhir dari penelitian ini menunjukkan adanya perbedaan tata kelola taman kota ramah hak asasi manusia untuk Taman Kartini dan Taman Fatmawati.

Berdasarkan hasil analisis, tata kelola pada tahap perencanaan dan implementasi antara Taman Kartini dan Taman Fatmawati secara garis besar memiliki kesamaan. Perbedaan tata kelola taman terdapat pada tahap pemeliharaan di mana Taman Kartini dikelola oleh Pemerintah Kabupaten Wonosobo, sedangkan Taman Fatmawati dikelola oleh Pemerintah Provinsi Jawa Tengah dan Pemerintah Kabupaten Wonosobo. Meski tata kelola yang telah dilakukan oleh pemerintah saat ini masih belum optimal, namun bagi masyarakat keberadaan Taman Kartini dan Taman Fatmawati sudah cukup memberikan ruang terbuka hijau di Kabupaten Wonosobo. Berdasarkan hasil kuesioner, masyarakat menilai kondisi kedua taman sudah baik hingga sebesar $62,7 \%$. Hal tersebut dapat menjadi suatu faktor pendorong bagi pemerintah untuk terus memperbaiki tata kelola taman kota yang ada di Kabupaten Wonosobo.

Tata kelola taman kota ramah hak asasi manusia dapat terwujud dengan cara menerapkan prinsip tata kelola ramah hak asasi manusia. Melihat dari penerapan prinsip-prinsip yang harus ada dalam melakukan tata kelola taman kota ramah hak asasi manusia, terdapat prinsip kunci yang harus diakomodir. Prinsip yang dimaksud adalah prinsip partisipatif, prinsip akuntabilitas dan prinsip transparansi. Hal tersebut sesuai dengan pemahaman tata kelola menurut Healey (2015) yaitu penyelenggaraan manajemen pembangunan yang bertanggung jawab melalui pelibatan seluruh stakeholder. Selanjutnya, sistem tata kelola taman kota ramah hak asasi manusia di Taman Kartini dan Taman Fatmawati dapat diimplementasikan pada taman-taman lain yang memliki peruntukan serupa yaitu taman ramah hak asasi manusia meliputi taman ramah anak, taman ramah lansia, maupun taman ramah difabel.

Rekomendasi diberikan pada setiap tahapan tata kelola. Berikut rekomendasi pada tahap perencanaan, implementasi dan pemeliharaan.

a. Tahap Perencanaan
- Pemerintah dapat mengadakan sosialisasi kepada masyarakat terkait dengan program kota ramah hak asasi manusia khususnya taman kota ramah hak asasi manusia supaya masyarakat paham akan arti, maksud, dan tujuannya. Sosialisasi dapat melalui media cetak ataupun online. Pengadaan acara-acara yang bertemakan ramah hak asasi manusia juga dapat dilakukan untuk menarik perhatian masyarakat.

- Peningkatan dan pemfokusan peruntukan taman perlu dilakukan oleh pemerintah. Taman Kartini dan Taman Fatmawati yang semula taman hanya berkonsep taman ramah hak asasi manusia, kedepannya diharapkan mampu untuk berubah menjadi taman tematik sehingga tujuan, sasaran dan fungsi taman akan lebih jelas. Taman tematik juga akan mempermudah masyarakat dalam memilih taman yang sesuai dengan kebutuhannya.

- Masyarakat dapat memberikan kritik dan saran pada saat proses perencanaan secara lebih bebas dan berkelanjutan seperti melalui media online. Penyampaian ini dimaksudkan agar pemerintah dapat terus memperbaiki perencanaan taman secara berkelanjutan. Pemerintah juga dapat menentukan peruntukan taman yang sesuai dengan kondisi kebutuhan di masyarakat sehingga apabila taman sudah terbangun dapat dimanfaatkan secara maksimal oleh masyarakat.

b. Tahap Implementasi

- Pemerintah dan pihak swasta memiliki tanggung jawab dalam penyelesaian pembangunan taman kota dengan tepat waktu. Hal tersebut menuntut supaya agenda pembangunan taman kota yang meliputi desain, pemanfaatan dana, dan jangka waktu pembangunan harus jelas.

- Penyediaan fasilitas-fasilitas dalam taman kota dapat dilakukan melalui kerjasama antara pemerintah dengan pihak swasta dengan sistem CSR. Hal ini bertujuan untuk menekan biaya operasional pembangunan taman.

- Desain taman dapat dikaji ulang untuk dapat memenuhi kebutuhan masyarakat terhadap fasilitas-fasilitas ramah hak asasi manusia seperti jalur khusus difabel dan wahana 
permainan anak. Desain taman juga disesuaikan dengan peruntukan khusus taman sehingga fasilitas yang ada dapat dimanfaatkan secara maksimal, efektif dan efisien.

c. Tahap Pemeliharaan

- Perlu adanya pengawasan terhadap jalannya perawatan rutin dan perawatan berkala yang dilakukan pada Taman Kartini serta Taman Fatmawati.

- Bagi Taman Kartini, perlu adanya penambahan petugas keamanan. Keamanan sangat dibutuhkan untuk menekan tindakan kriminalitas yang dapat dilakukan di taman kota.

- Pihak pengelola taman diharap lebih responsif terhadap kerusakan-kerusakan pada fasilitas taman kota. Perbaikan dan peremajaan atau penambahan fasilitas baru perlu dilalukan, seperti:

- Taman Kartini: Perbaikan wahana permainan anak, perbaikan kran air siap minum, dan penambahan vegetasi peneduh.

- Taman Fatmawati: Perbaikan lampu taman, perbaikan ruang laktasi, dan penambahan wahana permainan anak.

- Dinas Lingkungan Hidup dan Kehutanan Kabupaten Wonosobo dapat melakukan pembinaan dan pengarahan secara intensif kepada Komunitas Hijau penggiat lingkungan yang ada di Kabupaten Wonosobo.

- Masyarakat, khususnya pengunjung taman, diharapkan untuk ikut merawat dan menjaga taman dengan tidak merusak fasilitas yang sudah disediakan dan tidak membuang sampah sembarangan. Tujuannya untuk tetap menjaga kebersihan dan keindahan taman kota.

- Penggunaan taman kota oleh komunitas dan masyarakat baik pada Taman Kartini maupun Taman Fatmawati dapat dilakukan secara bijak. Imbauan kepada masyarakat diperlukan supaya taman kota tidak disalahgunakan untuk tindakan-tindakan yang merugikan seperti perkelahian, minuminuman keras, dan tindakan asusila pasangan.

- Masyarakat dapat membentuk komunitas penggiat lingkungan yang baru atau mengikuti suatu Komunitas Hijau penggiat lingkungan yang dibina oleh Dinas Lingkungan Hidup dan Kehutanan Kabupaten Wonosobo.

\section{DAFTAR PUSTAKA}

Arts, K. (2017). Inclusive Sustainable Development: a Human Rights Perspective. Current Opinion in Environmental Sustainability, 24, 58-62. doi:10.1016/j.cosust.2017.02.001

Budihardjo, E., \& Sutarjo, D. (2009). Kota Berkelanjutan (Sustainable City). Bandung: PT Alumni.

Cochran, W. G. (2001). Teknik Penarikan Sampel. Jakarta: UI Press.

Frazier, A. E., \& Bagchi-Sen, S. (2015). Developing Open Space Networks in Shrinking Cities. Applied Geography, 59, 1-9. doi:10.1016/j.apgeog.2015.02.010

Healey, P. (2015). Planning Theory: The Good City and Its Governance. In J. D. Wright (Ed.), International Encyclopedia of the Social \& Behavioral Sciences (Second Edition) (pp. 202-207). Oxford: Elsevier.

Nazir, M. (2003). Metode Penelitian. Jakarta: Ghalia Indonesia.

Omar, D. b., Ibrahim, F. I. b., \& Mohamad, N. H. b. N. (2015). Human Interaction in Open Spaces. Procedia - Social and Behavioral Sciences, 201, 352-359. doi:10.1016/j.sbspro.2015.08.186

Pradjasto, A., Gofar, F. A., Louisa, M., \& Mugiyanto. (2015). Panduan Kabupaten dan Kota Ramah Hak Asasi Manusia. Jakarta: International NGO Forum on Indonesian Develompment.

Purnomohadi, N. (2006). Ruang Terbuka Hijau sebagai Unsur Utama Tata Ruang Kota. Jakarta: Direktorat Jenderal Penataan Ruang, Departemen Pekerjaan Umum.

Sarhan, A.-A., Farghaly, Y., \& Elsayed, R. (2016). Measures and Attributes for Sustainability of Parks. Procedia Environmental Sciences, 34, 453-460. doi:10.1016/j.proenv.2016.04.040

Sugiyono. (2007). Metode Penelitian Kuantitatif, Kualitatif, dan R\&D. Bandung: CV Alfabeta.

Suryokusumo, R. F. A. (2008). Pelayanan Publik dan Pengelolaan Infrastruktur Perkotaan. Yogyakarta: Sinergi Publishing. 
Syam, S. B. (2014). Evaluasi Taman Umum di Kota Luwuk.

Diakses dari http://repository.unhas.ac.id:4002/digilib /gdl.php?mod=browse\&op=read\&id=-syaifulbah-

11109\&PHPSESSID=f528421bf0dc3de9d7 c91897eaa649fc, 26 Februari 2018

Turan, S. Ö., Pulatkan, M., Beyazlı, D., \& Özen, B. S. (2016). User Evaluation of the Urban Park Design Implementation with Participatory Approach Process. Procedia - Social and Behavioral Sciences, 216, 306-315. doi:10.1016/j.sbspro.2015.12.042

Wisnu, A. (2015). Asal Usul Wonosobo Menjadi Contoh Kabupaten Ramah HAM. Diakses dari

https://nasional.tempo.co/read/715908/ asal-usul-wonosobo-jadi-contohkabupaten-ramah-ham, 12 Maret 2018

World Human Rights Cities Forum. (2011). Gwangju Declaration on Human Right City. Diakses dari Korea: https://www.uclgcisdp.org/sites/default/files/Gwangju_De claration_on_HR_City_final_edited_versi on_110524.pdf

Yung, E. H. K., Conejos, S., \& Chan, E. H. W. (2016). Social Needs of the Elderly and Active Aging in Public Open Spaces in Urban Renewal. Cities, 52, 114-122. doi:10.1016/j.cities.2015.11.022 